\title{
GOVERNMENT ADMINISTRATION AS THE MAIN PREREQUISITE FOR NARROWING THE CORRUPTION SPACE
}

\author{
Oksana Safonchyk ${ }^{1}$, Artem Ripenko²
}

\begin{abstract}
Political corruption as a social phenomenon exists in virtually all countries of the world, including those that most researchers consider as "benchmarks" in terms of the development of democracy. At the same time, there is a steady tendency towards the growth of political corruption and the evolution of corruption practices in developed democratic countries. Problems of political corruption in the professional literature are given a lot of attention but the issues related to the peculiarities of the experience of fighting political corruption in the EU in the context of the introduction of appropriate practices in Ukraine remain insufficiently researched. In the context of reforming the modern Ukrainian society, the study of problems of preventing and counteracting corruption is extremely relevant for a number of reasons: firstly, corrupt practices in the government machinery are the main obstacle to the implementation of any reforms; secondly, the high level of corruption in society, as evidenced by the results of the World CPI Corruption Perception Index 2015, decreases public confidence in the government; thirdly, it is necessary to implement the anti-corruption recommendations of the Action Plan on Visa Liberalization from the European Union (EU); fourthly, the reduction of corruption would contribute to attracting international investment, and so on. The purpose of the article is to identify features of counteraction to corruption in the countries of the European Union and to analyse the formation of government administration as the main precondition for narrowing the corruption space. To achieve this purpose, the following goals were set: to determine the level of implementation of international anti-corruption standards in the government practice of Ukraine; to investigate the formation and development of anti-corruption institutions; to analyse the experience of anti-corruption institutions in the EU; to investigate the formation of informational transparency of government space; to analyse the ratings of Ukraine regarding data openness; to find out the features of E-Declaration models as an element of public control of anti-corruption institutions in the system of public administration. Reaffirming its European aspirations, during 2001-2018, Ukraine ratified several laws in relation to the formation of anti-corruption standards: a) general and on liability for corruption offenses and offenses related to corruption; b) documents on the activities of specialized agencies for fighting corruption; c) documents on ethical rules, anti-corruption restrictions and prohibitions for certain officials and on the prevention of political corruption; d) documents on the prevention of corruption in the economy and sports; e) documents on access to information. This allows asserting that in general the legislative framework for the prevention of corruption in Ukraine has already been established. Despite the adoption of many laws, out of 200 anti-corruption measures, which, according to the State Program for the implementation of the Anticorruption Strategy, had to be implemented by state bodies by the end of 2018 , about 35\% had not been implemented. Anticorruption strategy for 2019 and subsequent years and the State Program for its implementation do not exist. Many important anti-corruption laws, which would help to further improve the Ukrainian economy, finance, the system of social protection of the population, and so on, were not adopted. Many of the problems that prevent effective use of the data obtained still need to be resolved. It is also necessary to find solutions for defining the electronic declaration of anti-corruption crusaders.
\end{abstract}

Key words: government administration, corruption, anti-corruption bodies, anti-corruption measures, ProZorro, E-Declaration.

JEL Classification: O17, F42, H11, D73, R10, K32

\footnotetext{
Corresponding author:

${ }^{1}$ National University "Odesa Law Academy"

E-mail: safonchyk.oksana@gmail.com

${ }^{2}$ Odessa Forensic Research Institute (ONDISE) of Ministry of Justice of Ukraine, Ukraine.

E-mail: ripenko@ukr.net

ORCID: https://orcid.org/0000-0003-4197-4840
} 


\section{Introduction}

Political corruption as a social phenomenon exists in virtually all countries of the world, including those that most researchers consider as "benchmarks" in terms of the development of democracy. So, according to Italian researchers D. Della Porta and A. Vannucci, the highly corrupted countries of the world are Belgium, Greece, Spain, Italy, and the "intermediate" countries - Austria, the USA, France, and Japan (Della Porta, 2006). At the same time, there is a steady tendency towards the growth of political corruption and the evolution of corruption practices in developed democratic countries (Official website, 2019). At the same time, political corruption takes on a particular significance in transitive societies, one of the features of which is the excessive politicization of the state administrative apparatus, which largely represents not so much the interests of the state and society but of specific political groups, which, in turn, are closely linked with big capital.

The problems of government corruption have long been in view of scientists, the problems of political corruption in transitional countries are considered by C. Wallace, C. Haerpfer, K. H. Pedersen, L. Johansen, R. Hislope, A. Sajó, S. Kotkin, M. Philp, Q. Reed, and others. The issues of political corruption in the professional literature are given a lot of attention but the issues related to the peculiarities of the experience of fighting political corruption in the EU in the context of the introduction of relevant practices in Ukraine remain insufficiently researched.

In the context of reforming the modern Ukrainian society, the study of problems of preventing and counteracting corruption is extremely relevant for a number of reasons: firstly, corrupt practices in the government machinery are the main obstacle to the implementation of any reforms; secondly, the high level of corruption in society, as evidenced by the results of the World CPI Corruption Perception Index 2015, decreases public confidence in the government; thirdly, it is necessary to implement the anti-corruption recommendations of the Action Plan on Visa Liberalization from the European Union (EU). Moreover, in conditions of deepening the sociopolitical and financial and economic crisis in Ukraine, corruption is a serious threat to the national security of the state. It has become one of the negative factors that significantly affect the effectiveness of the public administration system as a whole (Romaniuk, 2009).

Recently, certain legislative and organizational changes were made that could reduce the level of corruption in Ukraine, but the bodies and agencies created, as well as the anti-corruption legislation adopted, have not yet been properly implemented.

The purpose of the article is to identify features of counteraction to corruption in the countries of the European Union and to analyse the formation of government administration as the main precondition for narrowing the corruption space. To achieve this purpose, the following goals were set: to determine the level of implementation of international anti-corruption standards in the government practice of Ukraine; to investigate the formation and development of anticorruption institutions; to analyse the experience of anti-corruption institutions in the EU; to investigate the formation of informational transparency of government space; to analyse the ratings of Ukraine regarding data openness; to find out the features of E-Declaration models as an element of public control of anti-corruption institutions in the system of public administration.

\section{The methodology of research}

\subsection{Implementation of international anti-corruption standards in government practice of Ukraine}

The formation of an effective apparatus for combating political corruption in the system of public administration in the member states of the EU also has a number of serious problems. The main thing is the heterogeneity of legislation regulating relations in this area, which is conditioned by national traditions and history. The anti-corruption legislation in most states is quite new and, in many cases, insufficiently worked out. Some provisions in the EU states are enshrined at the constitutional level, and in some countries - in legislative acts (Official website, 2019). As a consequence, the approaches of the states to the implementation of the institutional mechanism also differ. There are several models of anti-corruption institutions operating in the $\mathrm{EU}$, differing in form, functions, and tasks, with certain national characteristics and peculiarities. In particular, there are distinguished (Bocharnykov, 2018; Official website, 2019):

- multipurpose bodies that have the powers of law enforcement bodies, as well as fulfil preventive functions;

- specialized services, agencies and/or departments for combating corruption in the system of law enforcement agencies;

- institutions for the prevention of corruption, policy development, and coordination.

All this directly affects the effectiveness of information, education, and political mechanisms in various states of the Union.

The formation of the national base of Ukraine in the fight against corruption is based on the relevant international anti-corruption conventions, other international legal instruments containing clear internationally accepted definitions of what actions should be considered corruptive offenses, which actors should be responsible for them, which sanctions and other criminal-legal measures should be imposed, etc. 
Confirming its European integration aspirations, during 2001-2018, Ukraine ratified the Council of Europe Criminal Law Convention on Combating Corruption as of January 27, 1999, the United Nations Civil Law Convention against Corruption as of November 4, 1999, the United Nations Convention against Corruption as of December 11, 2003, the Council of Europe Convention on Laundering, Search, Seizure and Confiscation of the Proceeds from Crime and on the Financing of Terrorism, the United Nations Convention against Transnational Organized Crime as of 15 November, 2000, and the Council of Europe Convention on the Manipulation of Sports Competitions as of September 18, 2014. Ratification of the Council of Europe's Civil Law Convention on Corruption allowed Ukraine to join the Group of States Against Corruption (GRECO) (Official website, 2019).

Based on the anti-corruption standards specified in these and other international documents, laws were adopted:

a) general and on liability for corruption offenses and offenses related to corruption: "On the Principles of State Anti-Corruption Policy in Ukraine (Anticorruption Strategy) for 2014-2017”, “On Prevention of Corruption", "On the Power Purge", certain provisions of the Criminal, Criminal Procedure, Civil, Civil Procedure Codes of Ukraine, the Code of Ukraine on Administrative Offenses, and the Code of Administrative Justice of Ukraine;

b) documents on the activities of specialized agencies for fighting corruption: "On the National AntiCorruption Bureau of Ukraine”, "On the Prosecutor's Office", "On the National Police", "On the State Bureau of Investigation", "On the Security Service of Ukraine", "On Operative Investigation Activity", "On the Organizational and Legal Foundations of Combating Organized Crime";

c) documents on ethical rules, anti-corruption restrictions and prohibitions for certain officials and on the prevention of political corruption: "On Civil Service", "On the Judicial System and Status of Judges", "On Political Parties in Ukraine", "On Election of the President of Ukraine”, "On Election of People's Deputies of Ukraine”, certain provisions of the Labour Code of Ukraine, etc.;

d) documents on the prevention of corruption in the economy and sports: "On Public Procurement", "On Protection of Economic Competition", certain provisions of the Commercial and Commercial Procedure Codes of Ukraine, "On Prevention of the Influence of Corruption Offenses on the Results of Official Sports Competitions", etc.;

e) documents on access to information: certain provisions of the Civil, Commercial, Budgetary, and Land Codes of Ukraine, laws "On the National Agency of Ukraine on Detection, Investigation and Asset Management of Corruption and Other Crimes",
"On State Registration of Legal Entities, Individual Entrepreneurs and Public Formations", "On State Registration of Property Rights to Real Estate and their Encumbrances", "On Road Traffic", "On State Land Cadastre", "On Television and Radio Broadcasting”, "On Openness of Use of Public Funds", "On Information", "On Access to Public Information", "On Access to Court Decisions", etc.

This allows asserting that in general the legislative framework for the prevention of corruption in Ukraine has already been established. Despite the adoption of many laws, out of 200 anti-corruption measures, which, according to the State Program for the implementation of the Anticorruption Strategy, had to be implemented by state bodies by the end of 2018, about $35 \%$ had not been implemented. Anticorruption Strategy for 2019 and subsequent years and the State Program for its implementation do not exist. Many important anticorruption laws, which would help to further improve the Ukrainian economy, finance, the system of social protection of the population, and so on, were not adopted.

\subsection{Formation and development of anti-corruption institutions}

The effectiveness of the application of provisions of the criminal law in general and to corruption acts in particular depends directly on the availability of specialized (that is, professional) politically independent law enforcement bodies entrusted with proper authority and resources, as provided by the existing anti-corruption conventions and other international legal instruments.

In 2015-2018, there were several such bodies in Ukraine: the National Anti-Corruption Bureau of Ukraine (hereinafter - NABU) and the Specialized Anti-Corruption Prosecutor's Office (SAPO), as an independent structural unit within the structure of the General Prosecutor's Office, as well as the State Bureau of Investigation (hereinafter - the SBI) and the National Agency on Corruption Prevention (NACP). The Ukrainian Parliament also adopted the longawaited Anti-Corruption Law, and Ukraine "came close up" to the creation of this anti-corruption institute (https://data.gov.ua).

Newly created institutions have the authority to fight corruption. In the future, there should also be created special units (divisions) of the criminal police that will investigate corruption offenses in accordance with the CPC, as well as a special pre-trial investigation body within the Ministry of Finance.

Unfortunately, the development of the political situation in the first half of 2019 proved that the activities of the newly formed bodies are not yet in line with the public request. In our opinion, this is related both to the functional weakness of the specialized anti-corruption 
institutions and to the unreformed judicial system (and in many cases, direct opposition).

For example, the introduction of an E-Declaration. Theoretically, this is an effective G2C and G2B interaction tool that has not been fully operational. During 2015-2017, only eight people were convicted in Ukraine for knowingly false declarations or avoidance, with two persons being released from punishment. No person was convicted of illegal enrichment. In fact, these two articles, specifically introduced in the Criminal Code of Ukraine for the better prevention of corruption, have practically not worked so far (Ukrainian Open Data Portal, https://data.gov.ua).

\subsection{The experience of the establishment of anti-corruption institutions in the EU}

The experience of creating special anti-corruption institutions and their first steps indicate that the process of their formation will require time and a whole series of politically complex measures. Among them, first of all, should be called:

- ensuring the real political independence of anticorruption law enforcement bodies. Obviously, solving this problem is very difficult without the real consensus of the main political forces on the country's anti-corruption agenda. In practice, this means that the principle of the independence of anti-corruption institutions should determine the legislative and resource provision of their activities by the state;

- an urgent problem is ensuring effective coordination of anti-corruption bodies. To this end, the NACP must finally become a state body that defines anticorruption policy, coordinates the implementation by all state bodies of the Anti-Corruption Strategy and relevant international obligations of Ukraine, identifies corruption risks in the activities of these bodies and eliminates them, detects offenses related to corruption, etc.;

- priorities for the further development of anticorruption legislation should be "closure" of the possibilities of avoiding punishment for corruption acts, coherence of relevant legislative and regulatory documents, clarification of the powers of anticorruption bodies, in particular, in terms of operationalsearch activities, etc. There is a need to introduce a single transparent system of criminal statistics, without which it is impossible to adequately assess the relevant trends; - the creation of the Anti-Corruption Court is and remains the top priority of anticorruption reform;

- it is critically important to introduce a system of automatic verification of electronic declarations;

- successful reformation of the criminal justice system, the priorities of which should be to reduce the discretion of judges, prosecutors, investigators, increase their control and responsibility, primarily disciplinary, with the participation of the public in disciplinary proceedings.
Without such measures, "simple" replacement in the course of judicial reform of some judges or prosecutors in other and ordinary courts on specialized anti-corruption courts cannot substantially change something in the criminal justice system. One of the key prerequisites for the successful formation and establishment of the institutional framework for combating corruption is the large-scale and effective cooperation between reformers and civil society. First of all, it is about countering the active attempts of interested parties to use the fight against corruption in their own narrow political and economic interests and thereby discredit the anticorruption reform.

\section{Results and discussion}

\subsection{Formation of informational transparency of government space}

Access to most state registers and other data at the disposal of government agencies is actually monopolized by the relevant government agencies. By the end of 2013, there were only single registers open for public use (for example, the Unified State Register of Legal Entities and Individual Entrepreneurs) (Ukrainian Open Data Portal, https://data.gov.ua).

The receipt of many types of information (including from the registers) was accompanied by the need for appeals to government agencies, and the data of most registries remained publicly closed, which contributed to the existence of shadow schemes for their use. For example, information about registered rights to real estate has always been available only for owners and authorities themselves. This situation has contributed to fraud with real estate, in particular when buying and selling the property, because it was difficult to verify the real belonging of trade objects. At the same time, by shielding the argument about the protection of private life of citizens, the authorities restricted the public's ability to control the authorities and identify corruption cases (State Register of Real Property Rights to Real Estate, 2019).

Corrupt schemes also involved the use of public registers in the interests of commercial entities. The scandal with the electronic registries of the Ministry of Justice, the administration and management of which for many years was carried out by two private entities, became the most widely publicized. The state bought the relevant services without an open tender and promised not only to pay for registry service but also to pay additional monthly royalties for each appeal to the registry programs (CMU Resolution dated 21.10.2015). Thus, powerful corruption schemes were created around the registers of civil legal relations, which allowed private entities and their counterparts to make royalties more than the cost of these registers (Butusov, 2013). In the period from 2006 to 2013, the amount of 
royalties for private companies exceeded 760 million UAH. And only in 2014, the Ministry was able to stop payments under fictitious contracts (Ukrainian Open Data Portal, https://data.gov.ua).

For years, information on public finances remained closed. Separate aggregated figures on the fulfilment of state and local budgets were published by the State Treasury and the Ministry of Finance. However, the detailed information on the financing of certain budget items at the state level was traditionally lacking. Data on the implementation of individual local budgets was even less accessible, which allowed the authorities to inefficiently use public funds and obtain additional benefits for themselves. Closure of procurement information generated and fuelled corruption schemes in this area.

The spread of open data has become today one of the main tools for fighting corruption in the world, which emphasizes the importance of Ukrainian reforms in this area.

In 2015, the governments of the G20 agreed on the G20 Anti-Corruption Open Data Principles. Their content is simple - in order to stop corruption, important information should be public. Such openness is a prerequisite for the formation of an effective anticorruption policy aimed at overcoming bribery and nepotism (Open Data, 2019).

The dissemination of information was identified as one of the priority actions under the Anticorruption Strategy for 2014-2017, which was approved in the form of a law on October 2014. According to it, access to information that constitutes a public interest is recognized as "a necessary tool for conducting journalistic investigations, stimulating civic activity in the anti-corruption sphere." The anti-corruption strategy envisaged the implementation of a number of measures: changes to the legislation, inventory of public registers, dissemination of information on a single state open data portal, and participation of Ukraine in international initiatives (VRU Portal).

In April 2015, the Verkhovna Rada of Ukraine (VRU) adopted amendments to the Law of Ukraine "On Access to Public Information". According to it, public information officers are obliged to publish and regularly update it on a single public open data portal and on their websites.

In July 2015, the Law "On Amendments to Certain Legislative Acts of Ukraine on Enhancing Transparency in the Sphere of Property Relations for the Prevention of Corruption" was adopted, which opened access to the registers of property rights and land cadastre. As a result, at the year-end 2015, the opening of state registries was recognized as the most successful reform, as it expanded the scope for combating corruption (Bilan, 2016). The placement of registry data on the Internet should have eliminated corruption around access to such information. Besides, open registries made it easier for corrupt officials to be searched for, as it is now harder to hide property that could have been acquired for proceeds of corruption (State Web Portal, 2017-2019).

In June 2014, the CMU also created an institution responsible for disseminating open data. Under the Government's decision, the State Agency for Science, Innovation and Informatization of Ukraine was transformed into the State Agency for E-Governance in Ukraine. The new central executive authority was entrusted with the functions of implementing state policy in the field of informatization, e-governance, the formation and use of national information resources, the development of an information society (VRU Portal).

In April 2014, the Unified State Open Data Portal (http://data.gov.ua), created on the basis of similar Internet resources of other countries (for example, the data.gov portal in the USA created in 2009), was launched. As of January 2018, the portal hosts more than 28,000 data sets from about 2,000 information administrators. All data is divided into 15 categories: construction, state, ecology, economy, land, youth and sports, education and culture, healthcare, taxes, agriculture, social protection, standards, transport, finance, justice. In December 2016, the number of data sets was only 8.5 thousand (from almost a thousand administrators), which may indicate a rapid filling of the portal.

Special attention should be paid to specialized open-source data portals that have been created for three years. First and foremost, it is the Unified WebPortal for Public Funds Use, in which information is published in accordance with the Law of Ukraine "On the Openness of the Use of Public Funds" (adopted in February 2015) (VRU Portal). In September 2015, the Ministry presented the E-data portal (https://spending.gov.ua), which is an important tool for combating corruption. Access to information on the use of funds by the main spending units, the Pension Fund bodies, and the compulsory state social insurance funds is free and free of charge, which allows for monitoring and evaluation of the efficiency of the use of public funds. Since September 15, 2017, all public funds' spending units must necessarily publish the necessary information on the portal (VRU Portal).

Work is ongoing on the integration of the Public Finance Portal, the State Treasury Service, and the ProZorro system, which will allow tracking the flow of funds from tender to payment (Open Data, 2019). The openness of ProZorro's public procurements allows monitoring and evaluating their effectiveness, as well as identifying possible schemes and corruption risks. To evaluate procurement data, a public procurement module was launched (https://bi.prozorro.org).

An example of anticorruption direction is the disclosure of data on end-beneficiaries of Ukrainian companies for public access (Open Data, 2019). Ukraine was one of the first countries to introduce the latest 
Table 1

Analysis of operations in the ProZorro system for 2018-2019 in the Odesa region

\begin{tabular}{|l|c|l|c|}
\hline Number of tenders & 105,11 thousand people & Expected cost & 62,01 billion \\
\hline Number of organizers & 1,56 thousand & Savings & 1,16 billion. \\
\hline Number of participants & 16,23 thousand & Tenders & 2,43 \\
\hline
\end{tabular}

Source: compiled by the author (https://bi.prozorro.org)

FATF requirements for beneficiary owners. As early as October 2014, the VRU passed a law that included the term "final beneficiary" and disclosure requirements for end-owners (Svintsytskyi, 2018). As of the beginning of February 2018, only about 17 thousand companies in Ukraine did not provide information about their beneficiaries (VRU Portal). Ukraine became the first country to join the Global Beneficial Ownership Register. According to the Open Government's international multilateral initiative, such a change is "a great victory for the implementation of the principles of transparency and accountability" (Open Data, 2019).

Also, in the efforts to increase the effectiveness of the National Bank of Ukraine's supervision over banks, the Verkhovna Rada on March 2015 increased the responsibility of shareholders and bank management, which establish criminal liability of persons connected with the bank for any actions that led to the attribution of the bank to categories of insolvency, if this has caused material damage to the state or the lender.

The chart allows analysing the rating of the organizers in terms of the number of tenders, and the total savings made by the organizer for which the corresponding rating was awarded.

In April 2016, the NBU completed the main stage of work on disclosure of the ownership structure of Ukrainian banks, which resulted in identifying the actual controllers of each bank, and applied measures of influence within the limits of legislation to some banks (Ukraine opened, 2017). According to some experts, disclosure of information about beneficiary owners is a rare case where Ukrainian legislation is ahead of world standards of transparency (Ukraine opened, 2017).

The introduction of the relevant changes into Ukrainian laws has somewhat outpaced the EU Money Laundering Directive, which introduced a requirement for the establishment of a register of end-owners in the member states (adopted in May 2015) (VRU Portal). At the same time, unlike in Ukraine, access to such information in the EU may be limited to online registration, payment of administrative fees, and the need to provide evidence of the legitimate interest of the requesting persons. In the USA, such legislative initiatives are still in the process of discussion (Svintsytskyi, 2018). However, in Ukraine, there is a lack of tools for verifying beneficiary owners, which is an important prerequisite for transforming existing information into a genuine anti-corruption tool. It should be noted that open data not only enhances the possibilities of combating corruption but generally contributes to economic growth. According to some estimates, in 2018, open data has already brought 700 million USD to the Ukrainian economy. Herewith, if the pace of development of this sphere is maintained, this indicator can grow to 1.4 billion USD ( $0.92 \%$ of GDP) by 2025 (Open Data, 2019).

\subsection{Ukraine's ratings regarding data openness}

The progress of Ukraine in the reform of the field of open data has been reflected in the improvement of the relevant international ratings. According to the results of the study by the Open Data Barometer (made by the international non-governmental organization World Wide Web Foundation) in 2016, Ukraine took 44th place, which is 18 steps higher than in 2015 (The Open Data Barometer, 2016).

The organization's experts highly appreciated the introduction of open data in spheres such as business registration, primary and secondary education, criminal statistics, and the state budget (The Open Data Barometer, 2016).

However, serious problems remain concerning the openness of data on land ownership, geographic maps, the work of the healthcare system, and a number of other spheres. The progress of Ukrainian reforms in the field of open data was recorded in the Global Open Data Index (GODI) rating (Methodology. The Global Open Data Index, 2016). According to it, Ukraine in 2014 took 63rd place, in 2015 - 54th place, in 2016 it took 31 st place and is one of the world leaders by the possibilities of open data use (Places, 2018).

GODI includes an assessment of 15 categories of data (state budget, state statistics, purchases, etc.). In several spheres (state budget, national legislation, company registration), Ukraine occupied the first position since it provided for the free use of the specified data.

Besides, Ukraine is ahead of the vast majority of countries in the dissemination of open data on draft laws ( 7 th place), public procurement (11th place), and state statistics (38th place). At the same time, there are serious gaps in some fields (air and water quality, geographic maps, government expenditures) (Places, 2018). Thus, future reform efforts should be aimed at the industries, which identified the greatest problems with data openness, which will allow Ukraine to rise further in international rankings and improve its international image. 


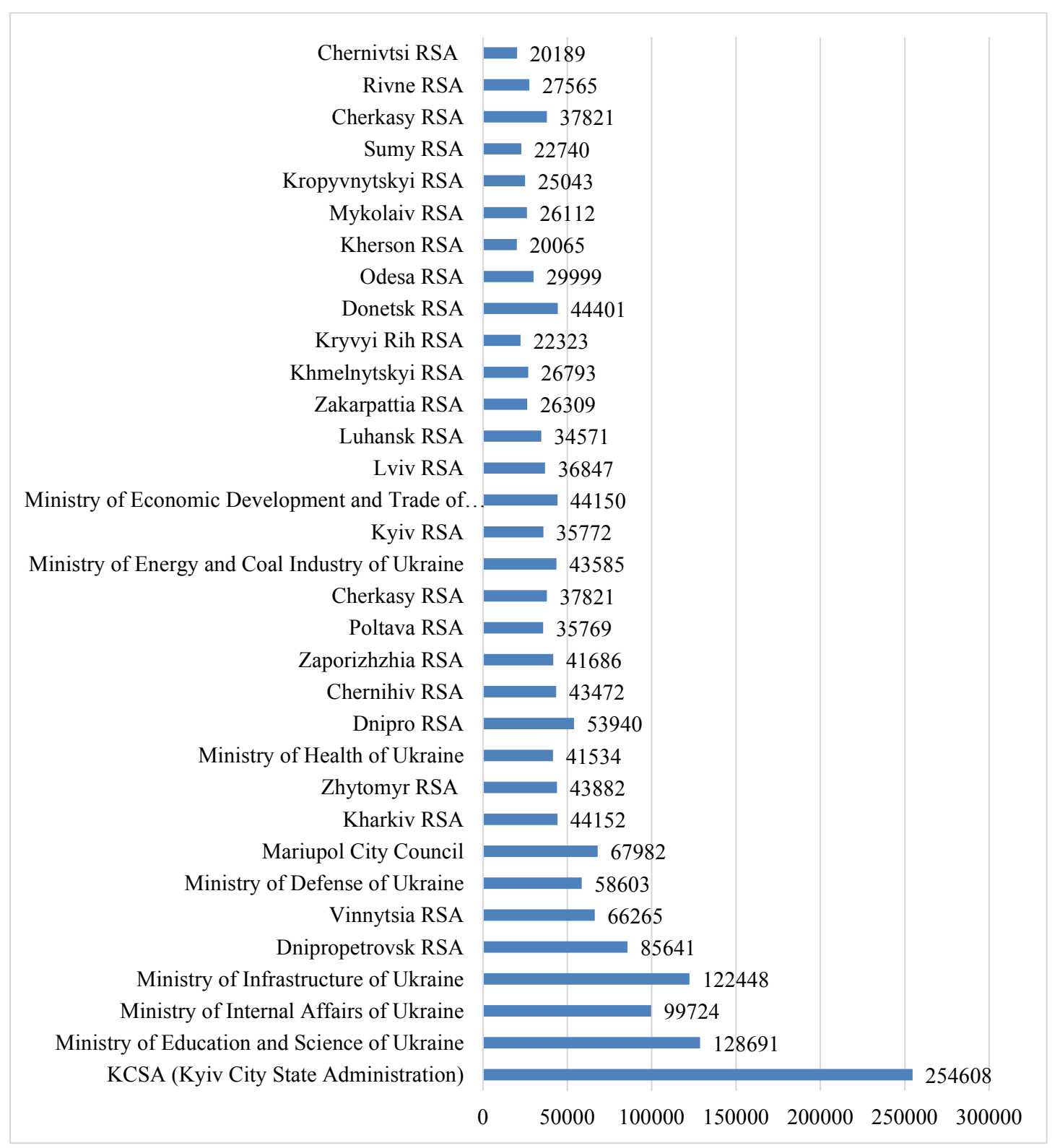

Figure 1. Organizers rating in the ProZorro system (2018-2019)

Source: https://bi.prozorro.org/sense/app/fba3f2f2-cf55-40a0-a79f-b74f5ce947c2

\subsection{E-declaration as an element of public control}

One of the key innovations in the anti-corruption system was the creation of a Unified State Register of Declarations of Persons Authorized to Perform Functions of the State or Local Governments. Previously, the system of declaring incomes of officials also existed in paper form (Khomenko, 2016). Paper declarations were submitted to the personnel service of the state authority, where the employee worked, and also kept there. Validation of declarations was carried out by the tax service; however, for obvious reasons, the effectiveness of this work was rather low. In addition, Ukrainian legislation did not criminalize the submission of knowingly false data, which led to the concealment of property and incomes of officials. Given these and other circumstances, the Anticorruption Strategy for 2014-2017 determined the need for the introduction of an electronic declaration system and a single electronic database of declarations as one of the priorities (VRU Portal (Anticorruption Strategy) for 2014-2017).

The new format of declarations has considerably expanded the categories of assets that need to be declared. If the paper declaration previously had 6 chapters, now it has 16. The electronic format of declarations and the creation of a unified portal have expanded public access to information on the income of government officials, which is an important anti-corruption tool. The work of the registry began in August 2016 under the Law of 
Ukraine "On Prevention of Corruption" (VRU Portal). Responsibilities for keeping the register were entrusted to the National Agency on Corruption Prevention (NACP), the central executive authority, which ensures the formation and implementation of anti-corruption policy. The NACP was created on March 2015, and its work was launched in March 2016, when a sufficient number of members of the agency had already been appointed (NACP).

In spite of technical problems, in September-October 2016, the first stage of submission of e-declarations for 2015 took place. According to the register, more than 118 thousand people had to submit documents (NACP). At the same time, since January 1, 2017, the circle of subjects of e-declaration has been substantially expanded (Radio Liberty, 2016). As a result, in 2017 almost 1.5 million electronic documents came to the USR, including 1.2 million of annual ones. As of April 2018, the number of uploaded documents already exceeds 2.6 million declarations and clarifications to declarations.

It should be noted that in March 2017, the Verkhovna Rada voted to amend the Law "On Prevention of Corruption", which obliged anti-corruption activists to submit e-declarations. Such changes caused criticism of these activists and international partners of Ukraine. Bills that proposed to cancel electronic declaration for anticorruption crusaders or change it have already been submitted to the Parliament. However, Ukrainian parliamentarians did not resolve this issue until the end of the period of electronic declaration (by April 1, 2018) (NACP, 2016-2019).

\section{Conclusions}

The formation of an effective apparatus for combating politicalcorruption in the system of publicadministration in the EU member states also has a number of serious problems. The main thing is the heterogeneity of legislation regulating relations in this area, which is conditioned by national traditions and history. There are several models of anti-corruption institutions operating in the EU, differing in form, functions, and tasks, with certain national characteristics and peculiarities. In particular, there are distinguished: multipurpose bodies that have the powers of law enforcement bodies, as well as carry out preventive functions; specialized services, agencies and/or departments for combating corruption in the system of law enforcement bodies; institutions for the prevention of corruption, policy development, and coordination.

Reaffirming its European aspirations, during 2001-2018, Ukraine ratified a number of laws in relation to the formation of anti-corruption standards: a) general and on liability for corruption offenses and offenses related to corruption; b) documents on the activities of specialized agencies for fighting corruption; c) documents on ethical rules, anti-corruption restrictions and prohibitions for certain officials and on the prevention of political corruption; d) documents on the prevention of corruption in the economy and sports; e) documents on access to information.

This allows asserting that in general the legislative framework for the prevention of corruption in Ukraine has already been established. Despite the adoption of many laws, out of 200 anti-corruption measures, which, according to the State Program for the implementation of the Anticorruption Strategy, had to be implemented by state bodies by the end of 2018 , about $35 \%$ had not been implemented. Anticorruption strategy for 2019 and subsequent years and the State Program for its implementation do not exist. Many important anticorruption laws, which would help to further improve the Ukrainian economy, finance, the system of social protection of the population, and so on, were not adopted.

Many of the problems that prevent effective use of the data still need to be resolved. It is also necessary to find solutions for defining the electronic declaration of anticorruption crusaders.

The main proposals for further development. According to the Anti-Corruption Strategy for 2014-2018, providing open access to publicly-important information was identified as one of the priority areas for action in the field of corruption prevention. The necessary legislation was adopted, an open data portal was created, and access to several information bases was opened.

Such changes have been reflected in the improvement of Ukraine in a number of international ratings. However, in order to protect these achievements and further progress in ensuring information openness, the pace of reforms must be preserved. Open data should remain one of the priorities of the anti-corruption policy, in particular, should be included in the new anticorruption strategic documents.

It should be noted that the draft Anti-Corruption Strategy for 2018-2020, issued on September 2017, no longer included measures to ensure access to information, although reforms in this area are still far from done.

We propose the following steps, the formation and development of government administration as a prerequisite for narrowing the corruption space, which in our opinion will be interesting for EU countries too.

1. To make legislative changes in order to create guarantees of the proper quality of open data and access to them. In particular, it is necessary to solve the problem of duplication of the functions of registries and to increase the responsibility for non-compliance with the requirements of the relevant legislation.

2. Monitor the dynamics of international ratings (Open Data Barometer and Global Open Data Index) to determine the priority changes concerning data openness. In certain spheres (state budget, national legislation, company registration), Ukraine is the world leader in 
providing access to information, but it lags significantly behind in other spheres (environmental data, geographic maps, healthcare). Solving social problems should be a priority to maintain transparency in governance. In some cases, this requires legislative changes and the creation of appropriate infrastructure; properly provide (financially and technically) state registries, which should help to increase the volume and quality of data. Today, some state registries are incomplete, which makes it difficult to work with them. For example, only $7 \%$ of the monuments are displayed in the State Register of Immovable Monuments of Ukraine.

3. Creation of appropriate information analysis tools that will allow the effective use of large volumes of open data, which became available as a result of the reform. In addition, it is necessary to ensure the integration of databases, which will improve the possibilities to analyse information.

\section{References:}

Analytical portal (2016-2019). Qlik Sense Hub. Retrieved from: https://bi.prozorro.org/sense/app/fba3f2f2cf55-40a0-a79f-b74f5ce947c2

Bocharnikov I.V. (2018). Foreign experience in counteracting corruption. Retrieved from: http://www.budgetrf.ru

Butusov, Yu. (2013). The attempt on the state register: the history of one of the most grateful things in Ukraine. Dzerkalo Tyzhnya, 4.10.2013. Retrieved from: https://dt.ua/internal/zamah-na-derzhreyestri-istoriya-odniyeyi-znayzuhvalishih-oborudok-v-ukrayini-_.html

Bilan, O. (2016). 5 Reforms That Change Ukraine. VoxUkraine, January 7 2016, Retrieved from: https://archive.voxukraine.org/2016/01/07/5-reform-yaki-zminiyut-ukrainu-ua

CMU Resolution dated 21.10. 2015. No. 835 "On Approval of the Provisions on Data Sets to be Disclosed in the Form of Open Data". Retrieved from: http://zakon5.rada.gov.ua/laws/show/835-2015-\%D0\%BF

Farhan Hameed (2005). Fiscal Transparency and Economic Outcomes, December, 2005. Retrieved from: https://www.imf.org/external/pubs/ft/wp/2005/wp05225.pdf

Khomenko, S. (2016). What is e-declaration and what's its problem? BBC Ukraine, 28.10. 2016. Retrieved from: http://www.bbc.com/ukrainian/politics/2016/10/161028_e_declarations_sx

Law of Ukraine (2014). "On the Principles of State Anti-Corruption Policy in Ukraine (Anticorruption Strategy) for 2014-2017" from 14.10. 2014. № 1699-VII. Retrieved from: http://zakon0.rada.gov.ua/laws/show/1699-18

Law "On the Principles of State Anti-Corruption Policy in Ukraine (Anticorruption Strategy) for 2014-2017" of October 14, 2014, № 1699-VII. Retrieved from: http://zakon0.rada.gov.ua/laws/show/1699-18

Law of Ukraine "On the Openness of the Use of Public Funds" № 183-VIII as of 11 February 2015. Retrieved from: http://zakon2.rada.gov.ua/laws/show/183-19

Law of Ukraine "On Amendments to Certain Legislative Acts of Ukraine Concerning the Determination of the Final Beneficiaries of Legal Persons and Public Figures" № 1701-VII as of 14.10.2014. Retrieved from: http://zakon5.rada.gov.ua/laws/show/1701-18/ed20141014

Methodology. The Global Open Data Index (2016). Retrieved from: https://index.okfn.org/methodology NAPC (2016-2019). National Agency for the Prevention of Corruption. Retrieved from: https://nazk.gov.ua

Official website (2019). Official website of The Organisation for Economic Cooperation and Development. Retrieved from: http://www.oecd.org/dataoecd/7/51/39972270.pdf

Open Data (2019). Open Data: Promise, but not Enough Progress from G20 Countries. Retrieved from: https://www.transparency.org/news/feature/open_data_promise_but_not_enough_progress_from_g20_ countries; Introductory Note to the G20 Anti-Corruption Open Data Principles

Porta D. Affairs (2006). Dirty deals: participants, resources and mechanisms of political corruption. Kyiv: K.I.S.

Portal of the Supreme Ode of Ukraine. Retrieved from: https://zakon.rada.gov.ua/laws

Places (2018). The Global Open Data Index. Retrieved from: https://index.okfn.org/place

Radio Liberty (2016). "The first stage of submission of e-declarations for 2015 ended - more than 118 thousand documents", Radio Liberty, 31.10.2016. Retrieved from: https://www.radiosvoboda.org/a/news/ 28084759.html

Romanyuk, B. V. (2009). World experience in the creation and operation of institutions for the prevention and fight against corruption. Scientific and practical journal, 21, 9-16.

Resolution of the Cabinet of Ministers of Ukraine dated October 21, 2015, № 835 "On Approval of the Provisions on Data Sets to be Released in the Form of Open Data". Retrieved from: http://zakon5.rada.gov.ua/laws/show/ 835-2015-\%D0\%BF

Svintsitsky, A. (2018). Disclosure of Beneficiary Owners: Formalities on Formalities, LigaZakon. Retrieved from: http://uz.ligazakon.ua/ua/magazine_article/EA007997

State register of real rights to real estate (2019). Retrieved from: http://kmp.ua/uk/analytics/exclusive/vidkrittyaderzhavnogo-restru-rechovih-prav/

The only public web portal for open data. Retrieved from: http://data.gov.ua 
The Open Data Barometer (2016). Retrieved from: http://opendatabarometer.org/?_year=2016\&indicator=ODB The state register of declarations. Retrieved from: https://public.nazk.gov.ua

Ukrainian Open Data Portal. Retrieved from: https://data.gov.ua

Ukraine Against Corruption (2018). Ukraine Against Corruption: Economic Front. Economic evaluation of anti-corruption measures in 2014-2018 - Dnipro: Serednyak T. Retrieved from: http://www.ier.com.ua/files/ publications/Policy_papers/IER/2018/Anticorruption_\%20Report_Ukr_pdf

Uniform State Register of Legal Entities, Individual Entrepreneurs and Public Associations. Retrieved from: http://data.gov.ua/passport/73cfe78e-89ef-4f06-b3ab-eb5f16aea237

Ukraine opened (2017). Ukraine opened up its beneficial ownership data: why it matters and how your country can be next, Open Government Partnership, June 08.2017. Retrieved from: https://www.opengovpartnership.org/ stories/ukraine-opened-its-beneficial-ownership-data-why-it-matters-and-how-your-country-can-be-next 